BEATA NAMYŚLAK

Uniwersytet Wrocławski

\title{
Kapitał zagraniczny w specjalnych strefach ekonomicznych w Polsce
}

Jednym z kierunków działania państwa w ramach polityki regionalnej jest wspieranie rozwoju regionalnego $\mathrm{z}$ wykorzystaniem takich instrumentów, jak zachęty finansowe dla przedsiębiorców. Dotyczy to szczególnie tych regionów, które potrzebują wysokiej dynamiki rozwoju w celu przezwyciężenia narastających problemów społecznych i ekonomicznych. Pozostawienie takich obszarów bez pomocy ze strony państwa może spowodować negatywne konsekwencje. Wobec bezlitosnych mechanizmów wolnego rynku może dojść do pogłębienia się, a następnie skrystalizowania dysproporcji w zakresie rozwoju gospodarczego regionów.

Powołanie specjalnych stref ekonomicznych w Polsce jest jednym z narzędzi polityki regionalnej, mających na celu stymulowanie napływu polskich i zagranicznych inwestycji do regionów przeżywających problemy gospodarcze. Specjalne strefy ekonomiczne funkcjonują również w innych państwach Europy, na kontynencie amerykańskim oraz azjatyckim. Zgodnie z pierwotnym wyobrażeniem stref, określanych w innych krajach mianem export processing zones, miały one charakter obszarów przemysłowych o dogodnych warunkach inwestowania (głównie fiskalnych) dla kapitału zagranicznego. Produkcja w strefach polegała na przetwarzaniu i importowaniu materiałów zwolnionych z opłat celnych i ich późniejszym eksporcie.

Specjalne strefy ekonomiczne w Polsce różnią się pod kilkoma względami od stref istniejących poza granicami kraju. Różnice tkwią m.in. w formie powoływania stref. W Polsce SSE są formą interwencji państwa z założeniem współpracy z władzami lokalnymi. W innych krajach strefy są inicjatywą władz regionalnych. Poza tym, różne jest podejście do liczby powoływanych stref. Przeważnie państwa starają się unikać tworzenia dużej liczby stref, gdyż prowadzi to do konkurowania o inwestora. Konkurencji tym silniejszej, im słabsza jest pozycja gospodarcza regionu. W przypadku istnienia większej liczby stref, sukcesy odnosi tylko nieliczna grupa, np. w Brazylii oczekiwane rezultaty ekonomiczne osiagnęła tylko 1 z 17 stref (Pancer-Cybulska 1999).

Kolejne różnice dotyczą lokalizacji stref. Przeważnie powstają one na obszarach przygranicznych i na wybrzeżach oraz w regionach o pogłębiającym się kryzysie gospodarczym, wymagających restrukturyzacji przemysłu. Tworzenie specjalnych stref ekonomicznych w Polsce odbywało się przeważnie na tych ostatnich z wymienionych obszarów. W starych okręgach przemysłowych powstało siedem SSE. Należą do nich: Katowicka, Wałbrzyska, Łódzka i Legnicka SSE oraz trzy strefy w Staropolskim Okręgu Przemysłowym: Mielecka, Tarnobrzeska i SSE „Starachowice”. Strefy powstały również w regionach o wyraźnie 
niskim poziomie rozwoju gospodarczego (Suwalska, Warmińsko-Mazurska) oraz na obszarach mogących stanowić bieguny przyspieszonego rozwoju ze względu na korzystne położenie (Kostrzyńsko-Słubicka, częściowo Suwalska). Mając na uwadze wymienione motywy lokalizacji oraz uwzględniając skalę problemów na omawianych obszarach, można stwierdzić, że strefy wymienione w grupie pierwszej stanowią ważny instrument wspierania rozwoju regionów, natomiast strefy należące do drugiej grupy mają jedynie szansę przyczynić się do zniwelowania problemów w regionie. W pozostałych przypadkach powołanie stref służy rozwiązywaniu problemów lokalnych, głównie problemu bezrobocia (Pomorska, Słupska, Kamiennogórska SSE). Dodatkowym atutem dla dwóch regionów okazały się obszary obecnie nie wykorzystywane gospodarczo, a wyposażone w infrastrukturę techniczną - tereny, na których stacjonowały wojska radzieckie w Legnickiej SSE i grunty przeznaczone pod budowę elektrowni atomowej w Żarnowcu w Pomorskiej SSE. Postanowiono również utworzyć technopark, stanowiący pomost pomiędzy wyższymi uczelniami a przemysłem (Krakowski Park Technologiczny) (Stryjakiewicz 1999, Polskie specjalne strefy... 2000).

Pierwotnie miały powstać w Polsce tylko dwie specjalne strefy ekonomiczne. Jednak po utworzeniu pionierskiej strefy Euro-Park Mielec we wrześniu 1995 roku, bardzo szybko podjęto decyzję o powołaniu kolejnych pięciu: Katowickiej, Suwalskiej, Łódzkiej, Wałbrzyskiej i Legnickiej, które rozpoczęły działalność do maja 1997 roku. Pozostałe strefy powstały w okresie od września 1997 roku do stycznia 1998 roku. Łącznie powołano aż 17 stref, z których dwie: Częstochowską i Mazowiecką, zamknięto w 1999 roku ze względu na brak zainteresowania zarówno inwestorów polskich, jak i zagranicznych. Z kolei 11 lipca 2001 roku utworzono Pomorską SSE, łącząc strefy „Żarnowiec” i „Tczew” oraz dodając gminy Kwidzyń, Krokowa i Starogard Gdański. Obecnie istnieje 14 specjalnych stref ekonomicznych, które rozmieszczone są na obszarze 12 województw i zajmują ogółem 5.744 hektary, co stanowi około $2 \%$ obszaru kraju użytkowanego przemysłowo ${ }^{1}$. Dwie strefy stanowią zwarty obszar, dwanaście zaś składa się z 2 do 9 podstref/obszarów przemysłowych (najsilniej rozczłonkowana jest Łódzka SSE).

Kapitał zagraniczny ulokowany jest w każdej strefie, na obszarze 11 województw (bez lubelskiego - w podstrefie Chełm, należącej do Mieleckiej SSE, nie ma inwestorów zagranicznych). Jednak osiągnięcia poszczególnych stref w zakresie wartości przyciągniętego obcego kapitału są bardzo zróżnicowane. Dane w tabeli 1 ukazują dystans oddzielający cztery/pięć stref, w których rzeczywiste efekty funkcjonowania kapitału zagranicznego są wyraźnie większe od pozostałych ${ }^{2}$.

\footnotetext{
${ }^{1}$ Pierwsza ustawa o specjalnych stref ekonomicznych z 20 października 1994 roku zakładała, że inwestor, który wybrał jedną ze stref nie płaci podatku dochodowego przez okres 10 lat i tylko 50\% jego wartości przez następne 10 lat. W zamian za ulgi inwestor jest zobowiązany do lokaty określonej wielkości kapitału (co najmniej 350 tysięcy - $2 \mathrm{mln}$ ecu - w zależności od strefy) lub/i utworzenia nowych miejsc pracy (co najmniej 40-100, również w zależności od strefy). W SSE inwestorzy nie mogli podejmować działalności takich, jak: produkcja paliw, wyrobów tytoniowych i napojów alkoholowych oraz gry i zakłady losowe.

Z początkiem 2001 roku znowelizowano tę ustawę. Podmioty, które rozpoczęły działalność po 1 stycznia 2001 roku są zwolnione z części obciążeń finansowych, pod warunkiem, że tworzą nowe inwestycje i nowe miejsca pracy. O wysokości zwolnień decyduje wartość nowych inwestycji i wartość kosztów nowych miejsc pracy. Przedsiębiorcy, którzy uzyskali takie zwolnienia, muszą kontynuować działalność gospodarczą przez 5 lat od momentu przyznania zwolnien. Spośród firm, które nie są nowymi inwestycjami, tylko podmioty zaliczane do grona małych i średnich przedsiębiorstw (MŚP) mogą starać się o zwolnienia podatkowe. Ograniczenia dotyczące rodzaju podejmowanej działalności obowiązują nadal.

2 Ankietę skierowano do zarządów specjalnych stref ekonomicznych działających obecnie w Polsce. Badanie przeprowadzono w październiku 2002 roku.
} 
Tabela 1. Inwestycje zagraniczne w specjalnych strefach ekonomicznych (stan na 31 czerwca 2002 roku)

\begin{tabular}{|c|c|c|c|c|c|c|c|}
\hline \multirow{2}{*}{$\begin{array}{c}\text { Specjalna } \\
\text { strefa ekonomiczna }\end{array}$} & \multirow{2}{*}{$\begin{array}{c}\text { Po- } \\
\text { wierzch- } \\
\text { nia } \\
\text { (ha) }\end{array}$} & \multicolumn{3}{|c|}{$\begin{array}{c}\text { Inwestycje zagraniczne } \\
\text { zrealizowane }\end{array}$} & \multicolumn{3}{|c|}{$\begin{array}{c}\text { Inwestycje zagraniczne } \\
\text { planowane }\end{array}$} \\
\hline & & Liczba & $\begin{array}{l}\text { Wartość } \\
(\mathrm{mln} \mathrm{zł})\end{array}$ & $\begin{array}{c}\text { Pracu- } \\
\text { jący }\end{array}$ & Liczba & $\begin{array}{l}\text { Wartość } \\
(\mathrm{mln} \mathrm{z})\end{array}$ & $\begin{array}{c}\text { Pracu- } \\
\text { jący }\end{array}$ \\
\hline SSE Euro-Park Mielec & 784,00 & 10 & $1.249,21$ & 2.661 & $1^{*}$ & 3,00 & 40 \\
\hline Kamiennogórska SSE & 250,96 & 5 & 0,10 & 120 & $* *$ & 12,00 & 228 \\
\hline Katowicka SSE & 826,99 & 28 & $3.869,73$ & 7.500 & $44^{*}$ & $4.126,00$ & 10.514 \\
\hline $\begin{array}{l}\text { Kostrzyńsko-Słubicka } \\
\text { SSE }\end{array}$ & 457,27 & 5 & 400,80 & 393 & $23^{*}$ & 128,28 & 870 \\
\hline $\begin{array}{l}\text { „Krakowski Park } \\
\text { Technologiczny” }\end{array}$ & 122,35 & 2 & 135,00 & 185 & $2^{*}$ & 270,00 & 650 \\
\hline Legnicka SSE & 442,00 & 9 & $1.207,50$ & 2.093 & $2^{*}$ & 22,00 & 80 \\
\hline Łódzka SSE & 283,10 & 13 & 191,80 & 603 & bd & bd & bd \\
\hline Pomorska SSE & 348,37 & 10 & 251,20 & 3.269 & $* *$ & 463,90 & 5.523 \\
\hline Słupska SSE & 135,87 & 2 & 3,81 & 38 & $2^{*}$ & 20,00 & 300 \\
\hline SSE „Starachowice” & 128,98 & 6 & 56,26 & 538 & $* *$ & 98,58 & 710 \\
\hline Suwalska & 331,30 & 4 & 37,47 & 459 & 4 & 15,80 & 290 \\
\hline $\begin{array}{l}\text { Tarnobrzeska SSE } \\
\text { „Euro-Park Wisłosan” }\end{array}$ & 786,80 & 9 & 171,50 & 843 & bd & bd & bd \\
\hline $\begin{array}{l}\text { Wałbrzyska SSE } \\
\text { „Invest-Park” }\end{array}$ & 474,00 & 14 & 583,04 & 4.769 & $3^{*}$ & 284,24 & 390 \\
\hline $\begin{array}{l}\text { Warmińsko-Mazurska } \\
\text { SSE }\end{array}$ & 372,00 & 3 & 20,74 & 248 & $2^{*}$ & 2,85 & 60 \\
\hline
\end{tabular}

* Dotyczy podmiotów, które uzyskały zezwolenie na prowadzenie działalności w SSE, ale jeszcze jej nie rozpoczęły.

** Plany inwestycje zadeklarowane przez podmioty działające w strefie. (Zarządy czterech stref uznały, że ze względu na pomyślność prowadzonych negocjacji nie mogą ujawnić informacji dotyczących firm, które rozpoczną działalność w strefie. Mogą jedynie określić plany inwestycyjne podmiotów już działających.)

Źródło: opracowanie własne

Najwięcej zagranicznych nakładów inwestycyjnych pozyskała Katowicka SSE - 3,87 mld zł, czyli ponadtrzykrotnie więcej niż następne w kolejności: Mielecka i Legnicka SSE, które zgromadziły po około 1,2 mld zł. Wymienione trzy strefy grupują łącznie $77,4 \%$ obcego kapitału w specjalnych strefach ekonomicznych w Polsce. Kapitał w wysokości 300 600 mln zł ulokowano w Kostrzyńsko-Słubickiej i Wałbrzyskiej SSE. Kolejną grupę tworzą Tarnobrzeska, Łódzka, Pomorska SSE oraz Krakowski Park Technologiczny, w których inwestycje zagraniczne osiagnęły wielkość rzędu 100-300 mln zł. Listę zamykają strefy z Polski północno-wschodniej: Warmińsko-Mazurska i Suwalska, Słupska oraz Kamiennogórska i strefa „Starachowice”. Trzeba jednak zaznaczyć, że z założenia celem Kamiennogórskiej SSE jest pozyskanie mniejszych inwestorów, podczas gdy pozostałe strefy nastawione są na duży kapitał. 
Zauważalne jest, że strefy o największych wartościach obcego kapitału są jednocześnie najdłużej działającymi (wraz z Suwalska). Zależność między wartością kapitału a stażem działalności strefy nie jest jednak przykładem zależności wprost proporcjonalnej, na przykład znacznie więcej kapitału skupiają strefy Legnicka i Wałbrzyska (obydwie powstały w maju 1997 roku) niż Suwalska (1 wrzesień 1996).

Największą liczbą podmiotów zagranicznych charakteryzują się Katowicka, Łódzka, Wałbrzyska i Mielecka SSE, czyli te strefy, które powstały w starych okręgach przemysłowych. Wiąże się to z potencjałem gospodarczym regionów, wyrażonym m.in. znaczną liczbą podmiotów już istniejących (możliwość przejęcia, kooperacja) oraz rozwiniętą infrastrukturą.

Uwzględniając wielkość zatrudnienia - tak istotną, mając na uwadze problemy gospodarcze w omawianych regionach - największy sukces osiagnęły strefy: ponownie Katowicka, dalej Wałbrzyska, Pomorska, Mielecka i Legnicka. Zatrudnienie w inwestycjach zagranicznych w pozostałych dziewięciu strefach osiagnęło wielkość 3427 osób, co stanowi $14,45 \%$ ogółu badanych. Stosunek liczby pracujących do liczby podmiotów pozwalający określić wielkość zakładanych podmiotów przyjmuje największe wartości w strefach takich, jak: Wałbrzyska (przeciętnie 340 osób), Pomorska (327), Katowicka (268), Mielecka (266) i Legnicka (233), zaś najmniejsze wartości cechują: Słupską (19 osób), Kamiennogórską (24) i Łódzką SSE (46) ${ }^{3}$. Ponadto inwestycje w strefie przyczyniają się do rozwoju innych podmiotów w otoczeniu strefy, a te korzyści są trudne do oszacowania. Uznaje się, że jedno miejsce pracy w strefie daje możliwość utworzenia kolejnego jednego do dwóch miejsc pracy w innym podmiotach.

Interpretacja wielkości planów inwestycyjnych jest utrudniona ze względu na różne podejście respondentów do tej kwestii (przypis pod tabelą 1). Ogólnie jednak, udostępnione dane dotyczące planowanych inwestycji pozwalają wysnuć hipotezę, że zaprezentowany układ SSE według ilości obcego kapitału będzie się dalej krystalizować. Relatywnie wysokie wartości zadeklarowanych planów dotyczą właśnie tych stref, które zgromadziły dotychczas największą ilość kapitału zagranicznego. Jako plany o istotnej skali można zakwalifikować także deklaracje inwestorów zagranicznych, którzy uzyskali już zezwolenie na prowadzenie działalności w Krakowskim Parku Technologicznym i w Kostrzyńsko-Słubickiej SSE. Wydaje się również wątpliwe wypełnienie deklaracji inwestorów w niektórych strefach, np. w Kamiennogórskiej SE, w której przez prawie 5 lat zrealizowano zaledwie $0,83 \%$ planowanych inwestycji. Co prawda, strefy zostały powołane na okres 20 lat, technoparki - na 15 lat, jednak największy dopływ kapitału ma miejsce na ogół w pierwszym okresie funkcjonowania stref.

Struktura branżowa analizowanych danych ukazuje przewagę pod względem ilościowym inwestycji w produkcji wyrobów z surowców niemetalicznych, w tym materiałów bu-

\footnotetext{
${ }^{3}$ Odrębnych badań wymaga określenie liczby podmiotów, które rozpoczęły działalność na obszarze specjalnych stref ekonomicznych po ich powołaniu do życia. Oddzielenie tej liczby od liczby inwestorów zagranicznych, którzy prowadzili działalność na omawianych obszarach, zanim utworzono strefę oraz liczby tych firm, które przeniosły się z terenów nie objętych zwolnieniami fiskalnymi (najczęściej pobliskich) do obszaru strefy, pozwoli uzyskać odpowiedź na pytanie: jaka jest wartość obcego kapitału, który napłynął bezpośrednio do specjalnej strefy ekonomicznej i ile nowych miejsc pracy utworzyli inwestorzy zagraniczni?

Wywiady autora z przedstawicielami wybranych SSE prowadzą do wniosku, że przypadki przeniesienia podmiotu zagranicznego do obszaru strefy są sporadyczne.

Nowelizacja ustawy o specjalnych strefach ekonomicznych ma m.in. na celu zwrócenie uwagi właśnie na ten problem (przypis 1).
} 
dowlanych (podsekcja DI według PKD), maszyn i urządzeń (DK) oraz wyrobów z metalu (DJ) (tab. 2). Produkcja podzespołów do samochodów (DM) ma miejsce w czterech strefach o największych nakładach inwestycyjnych. Układ ten różni się in plus od struktury branżowej wszystkich inwestycji zagranicznych wdziałalności produkcyjnej w kraju, w której w dalszym ciagu dominuje branża o najmniejszym udziale sektora $\mathrm{B}+\mathrm{R}$ - produkcja artykułów spożywczych i wyrobów tytoniowych (DA), wyprzedzając produkcję środków transportu (DM) (Zagraniczne inwestycje... 2001).

Tabela 2. Rodzaje działalności prowadzonej przez inwestorów zagranicznych w specjalnych strefach ekonomicznych (stan na 31 czerwca 2002 roku)

\begin{tabular}{|c|c|}
\hline $\begin{array}{l}\text { Specjalna strefa } \\
\text { ekonomiczna }\end{array}$ & Rodzaje działalności prowadzonej przez inwestorów zagranicznych \\
\hline SSE Euro-Park Mielec & $\begin{array}{l}\text { Produkcja części do środków transportu, maszyn, konstrukcji } \\
\text { i materiałów dla budownictwa oraz tworzyw sztucznych }\end{array}$ \\
\hline Kamiennogórska SSE & $\begin{array}{l}\text { Produkcja wyrobów z drewna, szkła gospodarczego, wyrobów ce- } \\
\text { ramicznych, betonowych i pasmanteryjnych }\end{array}$ \\
\hline Katowicka SSE & $\begin{array}{l}\text { Produkcja samochodów, maszyn i urządzeń, materiałów budowla- } \\
\text { nych, wyrobów ze szkła }\end{array}$ \\
\hline Kostrzyńsko-Słubicka SSE & $\begin{array}{l}\text { Najwięcej inwestycji dokonano w zakresie produkcji wyrobów pa- } \\
\text { pierniczych i spożywczych }\end{array}$ \\
\hline $\begin{array}{l}\text { „Krakowski Park } \\
\text { Technologiczny” }\end{array}$ & Poligrafia i mechatronika \\
\hline Legnicka SSE & $\begin{array}{l}\text { Produkcja części do samochodów, grzejników i kotłów centralnego } \\
\text { ogrzewania, mebli biurowych i wyrobów ceramicznych (porcelana } \\
\text { użytkowa) }\end{array}$ \\
\hline Łódzka SSE & $\begin{array}{l}\text { Produkcja maszyn i urządzeń, urządzeń elektronicznych, materiałów } \\
\text { budowlanych }\end{array}$ \\
\hline Pomorska SSE & Produkcja urządzeń elektronicznych i opakowań \\
\hline Słupska SSE & Produkcja maszyn i urządzeń oraz tworzyw sztucznych \\
\hline SSE „Starachowice” & $\begin{array}{l}\text { Poligrafia, produkcja maszyn i urządzeń, energii elektrycznej, kon- } \\
\text { strukcji budowlanych, wyrobów z kamienia naturalnego, odzieży }\end{array}$ \\
\hline Suwalska SSE & $\begin{array}{l}\text { Produkcja wyrobów papierniczych, wyrobów } \\
\text { z metalu i tworzyw sztucznych }\end{array}$ \\
\hline $\begin{array}{l}\text { Tarnobrzeska SSE } \\
\text { „Euro-Park Wisłosan” }\end{array}$ & $\begin{array}{l}\text { Produkcja konstrukcji metalowych, felg i odlewów aluminiowych, } \\
\text { części do łożysk tocznych, recycling }\end{array}$ \\
\hline $\begin{array}{l}\text { Wałbrzyska SSE } \\
\text { „Invest-Park” }\end{array}$ & Produkcja podzespołów do samochodów i materiałów budowlanych \\
\hline Warmińsko-Mazurska SSE & $\begin{array}{l}\text { Produkcja mebli i przetwórstwo drewna, produkcja materiałów bu- } \\
\text { dowlanych (gł. hydroizolacyjnych), obuwia, elektrotechnika }\end{array}$ \\
\hline
\end{tabular}

Źródło: opracowanie własne

Zauważalne jest silne rozczłonkowanie stref. Strefy rozrastając się, stają się coraz bardziej niespójne i niejednorodne. Nowe tereny, które wchodzą w skład stref legitymujących się kilkuletnim doświadczeniem w prowadzeniu działalności, mają zdecydowanie mniejsze 
zasoby obcego kapitału lub nie mają go w ogóle. Przykładami są podstrefy Radom w Tarnobrzeskiej SSE oraz Chełm i Gorlice w Mieleckiej SSE.

Rysuje się kilka zagrożeń dla funkcjonowania specjalnych stref ekonomicznych. Pierwszą $\mathrm{z}$ nich jest zakładanie stref na terenach zupełnie nieprzygotowanych pod inwestycje, ze słabo rozwiniętą infrastrukturą techniczną i drogową. Nakłady na budowę infrastruktury w strefach pochodzą z trzech źródeł: od spółki zarządzającej strefą, od samorządów oraz od inwestorów. Trzecia kategoria źródeł finansowania jest rzadko spotykana. Przeważają nakłady poniesione przez spółkę zarządzającą oraz przez samorządy. Należy zaznaczyć, że spółki zarządzające SSE dysponują niewielkimi środkami. Według założeń bowiem, w zagospodarowaniu stref wiodącą rolę powinny odgrywać samorządy lokalne. Jednak koszty jakie przeznacza samorząd na infrastrukturę, zbrojenie terenu są zdecydowanie za niskie. W trzech strefach (Mieleckiej, Suwalskiej i SSE „Starachowice”) samorządy lokalne w ogóle nie partycypowały w kosztach inwestycji w infrastrukturę. Najbardziej zaangażowane podejście samorządów miało miejsce w Katowickiej i Wałbrzyskiej SSE. Ogółem zaś najwięcej zainwestowano w infrastrukturę w strefach: Katowickiej (79 834 zł), Wałbrzyskiej (65 440 zł), Legnickiej (42 625 zł) i Mieleckiej (27 100 zł), czyli dokładnie w tych strefach, które zgromadziły największą wartość kapitału zagranicznego (Przygodzki 2002).

Drugim zagrożeniem jest konkurencja pomiędzy strefami, nie tylko pomiędzy SSE w Polsce, ale również z obszarami zwolnień podatkowych poza granicami kraju, np. w Czechach. Koncern Philips wybrał ostatecznie Czechy, a nie Katowicką SSE dla lokalizacji swojego oddziału w tej części Europy. Z kolei inwestycja koncernu Toyota powstanie w Wałbrzyskiej, a nie w Legnickiej SSE, mimo że to Legnicka SSE została wskazana jako pierwsza przez władze centralne.

Pomimo wymienionych powyżej problemów, efekty funkcjonowania specjalnych stref ekonomicznych są widoczne. Utworzenie zagłębia motoryzacyjnego na Górnym Śląsku czy zespołu podmiotów zajmujących się przetwórstwem rud aluminium w Stalowej Woli i jej okolicach to niewątpliwie zasługi istniejących stref. Poza tym strefy przyczyniają się, nawet jeśli nie do utworzenia nowych miejsc pracy, to do utrzymania istniejących. Pewnym mankamentem jest niestety to, że tylko część podmiotów działających w strefach przeznacza większość produkowanych dóbr na eksport (na podstawie innych badań autora), a przecież jest to jedno z podstawowych założeń specjalnych stref ekonomicznych.

\section{Literatura}

Polskie specjalne strefy ekonomiczne - zamierzenia i efekty, 2000, red. E. Kryńska, Warszawa Zagraniczne inwestycje bezpośrednie w Polsce w 2000 roku, 2001, NBP, Warszawa

Pancer-Cybulska E., 1999, Uwarunkowania samorzqdności lokalnych i regionalnych $w$ Polsce $w$ aspekcie kreowania i wzrostu konkurencyjności, [w:] Konkurencyjność regionów, red. M. Klamut, Wrocław, s. 220-249

Przygodzki Z., 2002, Efektywność specjalnych stref ekonomicznych (na przykładzie Łódzkiej Specjalnej Strefy Ekonomicznej), [w:] Przedsiębiorczość i innowacyjność jako czynniki rozwoju regionalnego i lokalnego, red. W. Kosiedowski, Włocławek, s. 379-395

Stryjakiewicz T., 1999, Adaptacja przestrzenna przemystu $w$ Polsce $w$ warunkach transformacji, Poznań 